\title{
Grape-vine Yellows - Aetiology, Epidemiology and Diagnosis
}

\author{
P.A. Magarey \\ Loxton Research Centre, Department of Agriculture, P O Box 411, Loxton, South Australia, 5333.
}

Submitted for publication: July 1986

Accepted for publication: September 1986

Keywords: Grape-vine Yellows, aetiology, epidemiology, diagnosis, control, Flavescence Dorée, procaryote, mycoplasma-like organism,

Scaphoideus titanus.

\begin{abstract}
Grape-vine Yellows comprise diseases with the same symptoms as Flavescence Dorée (FD), a disease severe in Southern France and Italy, and caused by a procaryote. Other members include Bois Noir, Goldgelbe Vergilbung, and Australian Grape-vine Yellows. Yellows diseases have been observed in Europe, Australia, Israel, U.S.A. and Chile. Symptoms include yellow leaves which curl downward, and fall prematurely. Shoots are stunted and remain unlignified, and bunches shrivel and fall at flowering. Baco $22 \mathrm{~A}$, Jurançon blanc, Riesling and Chardonnay, are among the most susceptible cultivars. Scaphoideus titanus, the leafhopper vector of FD, is controlled by insecticides and loss from FD is now minimal. The other yellows diseases are of lesser importance and their aetiology is unresolved. Further investigation is needed to clarify the taxonomy of Grape-vine Yellows but the current diagnosis of yellows diseases of grape-vine is dependent on symptoms and at least one of several other features.
\end{abstract}

The Grape-vine Yellows group of diseases have been of viticultural importance in many countries. The best known of the group is Flavescence Dorée (FD) which has been particularly devastating in French and Italian vineyards (Caudwell, Larrue et al, 1971).

A new and widespread disease in Australia recently has been described and named Australian Grape-vine Yellows (AGY) (Magerey \& Wachtel, 1983, 1986 a,b). An important factor in identifying that disease was its similarity to those in the Grape-vine Yellows group and to FD in particular. A literature review on that group of diseases therefore became an integral part of investigation into $\mathrm{AGY}$, to enable comparison of the respective diseases and resolution of potentially useful diagnostic techniques.

A difficulty for English reading investigators was that many papers had been published in other languages. Additionally there was little cohesion in recent literature on yellows diseases of grape-vines.

The present paper is intended to assist in both these aspects. It provides a unified English account of the information available on Grape-vine Yellows diseases, where necessary compiled from translation of papers on that subject. The literature review was current to December 1985.

\section{NOMENCLATURE OF GRAPE-VINE YELLOWS}

Grape-vine Yellows is the name given to a group of diseases of grape-vines that have the same symptoms and the same type of causal agent as FD which disease is economically the most important and is type-member of the group (Caudwell, Larrue et al, 1971).

Initially reported in France (Levadoux, 1955), Grape-vine Yellows diseases are now found throughout the viticultural regions of Europe and in many other countries (Goheen, 1977). Often their aetiologies have been only partly elucidated and the present taxonomy of Grape-vine Yellows diseases is justified mostly by disease symptomatology and where possible, by other more or less definitive evidence. It should therefore be considered temporary.

Grape-vine Yellows diseases have two aetiological features in common. Firstly, their symptoms are similar to FD. Secondly, there is evidence to infer that their causal agent is procaryotic. One disease, FD, has a mycoplasma-like (MLO) aetiology while others may be caused by Rickettsia-like organisms (RLO) (Rumbos \& Biris 1979), but the precise causal nature of most is not known.

The name Flavescence Dorée was coined by Levadoux (1955) for the disease later described by Caudwell (1964) and found to be transmitted naturally in grapevines and experimentally to broad bean, by the leafhopper Scaphoideus titanus. Caudwell, Larrue et al, (1971) reserved the name FD, for this and other grafttransmissible diseases with the same symptoms and vector.

Natural transmission of the Grape-vine Yellows diseases by $S$. titanus occurs in SW France and elsewhere (Caudwell, Larrue et al, 1978; Caudwell, Moutous et al, 1974; Osler, 1975) where it is known as FD.

Where natural transmission of the diseases has not been demonstrated, other names are given. A yellows disease in eastern France (Branas, 1956b; Caudwell, 1961a) and Switzerland (Bovey, 1970, 1972) is known as Bois Noir, and a similar disease in German Federal Republic is known as Goldgelbe Vergilbung (Gaertel, 1959), and in Australia as AGY (Magarey and Wachtel, 1986 a,b).

Similar symptoms have been reported on grape-vines from Roumania (Rafalia and Costache, 1970; Caudwell, Larrue et al, 1971; Caudwell \& Larrue, 1979), Hungary (Gaertel, 1974), Chile (Caudwell, Larrue et al, 1971; Caudwell, 1980b), Israel (Tanne \& Nitzany, 1973), Greece (Kyriakopoulou \& Bem, 1973), Portugal (Mendonca et al, 1974), U.S.A. (Uyemoto, 1974) and New Zealand (Bovey et al, 1980). In Chile the disease is known as Amarilliamento de Elqui, in Portugal as

I thank Drs A Caudwell and S C Brown for assistance in gathering information in France and M Winter, L Chevyl, M Fry, L Simian, $H$ Schmidt, and $F$ Korte for assistance in translating literature. Drs Caudwell and $G R$ Stirling and $M F$ Wachtel reviewed manuscripts. Philippians 4:19 
Enrolamento Foliar, and U.S.A. as Leaf Curl and Berry Shrival.

Elsewhere the diseases are loosely termed FD but as types distinct from FD, they would be more accurately described by their group name Grape-vine Yellows, until their aetiologies are better understood.

\section{FLAVESCENCE DORÉE}

Flavescence Dorée, literally "golden yellowing", caused serious loss in south-western France when it spread in epidemic form in 1955-60 (Caudwell \& Schvester, 1970). In Europe it is considered the most destructive of the virus and procaryotic diseases of grape-vines (Gaertel 1959).

\section{Distribution and Spread:}

Flavescence Dorée was first recorded in 1949 (Branas, 1956a; Caudwell, 1956) in Armagnac and Chalosse, near Bordeaux, (Caudwell, 1957; Gaertel, 1959). The disease spread rapidly as illustrated by the initial observation of one Baco $22 \mathrm{~A}$ vineyard in which $5 \%$ of vines were diseased and five years later, $97 \%$ of vines had been affected at least once (Caudwell, 1965a). The disease thus rapidly reached epidemic status (Caudwell, 1961a, 1964) spreading up to $10 \mathrm{~km}$ a year (Caudwell, 1957). This coincided with the arrival of an insect vector from U.S.A. (Caudwell \& Schvester, 1970).

The disease is now found throughout SW France and in the French Mediterranean (Caudwell \& Schvester, 1970), in northern Corsica (Caudwell, Moutous et al, 1974), and in Italy (Belli et al, 1973). These are the warmest regions of Europe and are bounded by latitudes $42^{\circ} \mathrm{N}$ and $45^{\circ} \mathrm{N}$.

\section{Symptoms:}

Seasonal development: Caudwell and others (Caudwell, 1957, 1964; Gaertel, 1959; Schvester, 1963; Caudwell \& Schvester, 1970; Bovey et al, 1980) have described the disease in detail. In spring vines show the first symptoms of FD. Bud burst is retarded and shoots are stunted. Obvious symptoms are not evident until early flowering and later when leaf veins begin to yellow and sectors of the blades become chlorotic. The leaves also curl downward.

The irregular chlorotic patches soon become necrotic and leaves fall prematurely. The intensity of leaf chlorosis varies among cultivars but the warmer the season, the earlier and clearer are symptoms expressed (Caudwell, 1957).

Diagnostic leaf symptoms are first seen later in summer when the leaves are strongly downward curled, thickened and brittle. They overlie one another like scales on a fish because shoot internodes are shortened and more so in dry conditions. Shoot apices cease activity and become necrotic. Affected shoots do not lignify but remain rubbery and thus often assume a weeping habit.

On affected shoots black pustules are usually formed near the basal ends. Diseased and unlignified shoots are killed by frosts during winter.

When shoots are infected late in the season there is a vertical demarcation between lignified and unlignified zones and lignification is more likely to occur at the nodes rather than in internodes. Green islands of unlignified internode tissue remain.
At or near flowering, young inflorescences on affected shoots shrivel and fall without setting fruit, leaving the shoots barren. Sometimes bunches are not affected until near veraison; then individual berries shrivel and the remaining berries, scattered on a bunch, fail to ripen.

A quick and easy technique using fluorescence microscopy, can detect diseased phloem cells which are yellowed and necrotic (Carle, 1965b,c).

Sugars accumulate in leaves of diseased shoots because necrotic phloem cells restrict the movement of photosynthates in diseased vines. This impediment causes the external symptoms (Caudwell, 1957), which are similar to those caused by restriction in the phloem cells in girdled or wounded shoots (Bovey et al, 1980).

Recovery and localisation: Typically in the first year of infection, the whole vine is severely diseased and crop loss is complete. Some of these vines die in this, the "crisis" (or shock) stage (Caudwell, 1957). In the second season the vines either recover and remain symptomless, or the disease in localised to a few shoots (Caudwell, 1957, 1961b, 1964).

The causal agent does not necessarily occur throughout the plant system and its distribution may be related to the amount of inoculum introduced by the vectors (Schvester, 1969). The proportion of previously diseased vines that recover, varies with the seasons (Caudwell, 1957) and has ranged from $7 \%$ to $85 \%$ (Caudwell, 1961b; Caudwell, 1965a).

If a vine recovers from disease and remains healthy for several years before again being infected, a second crisis stage will occur (Caudwell, 1965b). Thus different levels of disease severity occur on different vines and frequently only sectors of vines are diseased.

\section{Severity of Disease:}

The severity of FD varies with the age and cultivar of the vine and disease loss is more severe in vines in warmer aspects (Gaertel, 1959).

Death of bunches, characteristic of FD, is the chief cause of yield loss. Affected shoots are unproductive and the dense, fibrous pulp of shrivelled berries is bitter and unusable (Caudwell \& Schvester, 1970).

Caudwell $(1957,1964)$ made detailed studies of the effect of FD on the yield of vines. In the crisis stage of infection vines yield at least $74 \%$ less, and this reduction is greatest and continues for longer in vines first affected when only one or two years old.

Diseased shoots are stunted and frequently die reducing the number of shoots available for the next season's crop (Gaertel, 1959). Where FD is not controlled and vines are diseased year after year, vigour is progressively reduced and some vines die (Caudwell \& Schvester, 1970).

In the 1950 's up to $80 \%$ of vines in Armagnac were diseased and yield losses of $20 \%-30 \%$ were frequent (Caudwell, 1964); at times, these were as high as $80 \%-$ $100 \%$. However, since disease controls have been applied, its incidence has been reduced to $5 \%-10 \%$ and crop loss is negligible (Caudwell, Moutous et al, 1974).

In recent years a few growers have decided not to apply these controls and the incidence of disease in their vineyards has returned to $75 \%-80 \%$. 


\section{Cultivars Affected:}

Baco 22A, Jurançon, Aramon, and Nieluccio are particularly susceptible to FD (Caudwell, 1964, 1981) but no grape cultivar is entirely resistant (Caudwell \& Schvester, 1970).

During the late 1950's the susceptibility of some cultivars was assessed (Caudwell, 1957, 1965a; Gaertel, 1959; Schvester, Carle et al, 1967; Caudwell, Moutous et al, 1974; Moutous, 1977); these and later observations are summarised in Table 1.

\section{TABLE 1}

Susceptibility of some grape-vine cultivars to Flavescence Dorée

Very Susceptible

In Armagnac - Baco 22A, Jurançon blanc, Noah, 157 Gaillard, Aramon, Riesling, Chardonnay.

In Corsica - Alicante Bouchet, Malvoisie (Pinot gris), Nieluccio.

In Italy - Pinot noir, Pinot blanc, Chardonnay.

Susceptible

Ondenc, St. Emilion (Trebbiano), Grenache, Castel 1028.

\section{Moderately Tolerant}

Piquepoult (Folle Blanche), Baroque, Chasselas.

Most Tolerant

Seyve Villard 52-76, S.V. 12-375, Couderc 13, Seibel 2655, Colombard, Sauvignon, Semillon, Muscadelle, Cabernet.

\section{Cause of Disease:}

The cause of FD, like that of all diseases associated with MLO, has not been verified by fulfilment of Koch's postulates (Caudwell, 1980a) because of the difficulty in culturing MLO (McCoy, 1979). However, leafhopper-borne MLO are implicated as the pathogen of FD by several lines of evidence (Caudwell, Kuszala et al, 1973).

Electron microscopy (EM): Wall-less procaryotic bacteria-like organisms, considered MLO, have been observed in infectious extracts from leafhopper vectors, in the salivary glands of infectious leafhoppers, and in herbaceous hosts infected with FD (Caudwell, Giannotti et al, 1971; Caudwell \& Larrue, 1979; Caudwell, Meignoz et al, 1981, 1982). Diseased grape-vine phloem tissue, particularly in petioles, also contained very low numbers of MLO.

Because MLO have not been seen in symptomless hosts, in uninfectious leafhoppers, or in the purified extracts from uninfectious leafhoppers (Caudwell, Giannotti et al, 1971), there is positive correlation of MLO with insect infectivity and the expression of symptoms on grape-vine and broad bean.

The in vivo concentration of MLO in grape-vine and that achieved by improved extraction methods, does not exceed 105 or 106 units per $\mathrm{ml}$ (Caudwell, 1977) and that number is insufficient to study the particles in detail (Caudwell, 1978).

The transmission of infectivity to herbaceous hosts in the early 1970's was a significant breakthrough in overcoming the problem of low in vivo numbers in grapevine. Because the infective units multiply rapidly in broad bean, that host is now used almost exclusively for EM studies of the FD pathogen (Caudwell, Kuszala et al, 1970, 1972b, 1973; Caudwell, 1977).

Vector transmission: In both the field and the laboratory the cycle of disease is dependent on insect vectors (Caudwell, 1965a). In the field, the leafhopper S. titanus, persistently transmits the pathogen from diseased to symptomless vines (Schvester, Carle et al, 1961, 1963a,b). In the laboratory, the leafhopper Euscelidius variegatus transmits the pathogen from grape-vines to broad beans and other herbaceous hosts after acquisition from plants or purified extracts (Caudwell, Kuszala et al, 1970, 1972b).

Graft transmission: A low proportion $(10 \%-40 \%)$ of indicator grape-vines dormant-grafted with diseased material, express typical FD symptoms (Caudwell, $1957,1964)$ but transmission is irregular (Caudwell \& Larrue, 1979).

Heat therapy: Immersion in water at $30^{\circ} \mathrm{C}$ for three days reduced the infectivity of FD diseased grape-vine cuttings by $80 \%$ (Caudwell, 1966). A longer treatment was considered likely to eliminate infectivity.

Symptoms: Fluorescence microscopy has shown that disruptions of phloem tissue cause the symptoms of FD (Carle, 1965b,c; Caudwell, 1957). This is consistent with yellows diseases caused by phloem-inhabiting MLO in other hosts (Caudwell, 1965b, 1980a).

Survival in vitro: Caudwell, Kuszala et al, (1973, 1974a,b,c,d), have maintained the infective units of FD in vitro; they survived for periods of up to 44 hours (Caudwell, Kuszala et al, 1974a,b,c; McCoy, 1979) and at titres up to 106 units $/ \mathrm{m} l$ (Caudwell, Kuszala et al, 1976; Caudwell, Meignoz et al, 1981,82).

Some plant mycoplasma have been cultured for longer and at higher concentrations, but the culture of MLO associated with yellows diseases has rarely been achieved (Saglio \& Whitcomb, 1979).

Conclusion: Electron microscopical observations, insect and graft transmission studies, disease epidemiology, the heat lability of infectivity, and the nature and spontaneous remission of disease symptoms, imply MLO pathogenicity, consistent with other yellows diseases (Caudwell, 1978, 1980a; Nienhaus et al, 1978; McCoy, 1979). The impossibility of transmitting infectivity mechanically (Caudwell, 1957) and the difficulty in culturing the causal agents are also consistent with that of conditions observed in other $\mathrm{MLO}$ /yellows diseases. This is good evidence, although inconclusive, in support of MLO pathogenicity for FD.

\section{The Vector Scaphoideus titanus and Natural transmis- sion:}

Nomenclature: In most literature, including some recent papers, the leafhopper vector of FD is known as $S$. littoralis Ball. However, Barnett (1976) revised the Neartic species of Scaphoideus and listed S. littoralis as a synonym of $S$. titanus Ball, now the accepted name which ought to be used.

Discovery: S. titanus was found widespread in southern France but in low numbers (Bonfils \& Schvester, 1960). It appeared to develop exclusively on grape-vine (Schvester, Moutous, Bonfils et al, 1962) and, from ob- 
servation of disease distribution patterns (Schvester, 1963) and from insect feeding studies (Schvester, Moutous \& Carle, 1962), it was confirmed as vector of FD.

Distribution: S. titanus is native to USA (Barnett, 1976). It was introduced to France at the latest by the mid 1940's (Schvester, 1962) and has since spread throughout SW and southern France (Caudwell \& Larrue, 1979), to Corsica (Caudwell \& Schvester, 1970), Switzerland (Bagglolini et al, 1968) and Italy (Vidano, 1964).

The current distribution of the insect is very similar to that of FD and is thought to be the main factor in the spread of the disease. Caudwell and Larrue (1979) considered climatic factors the main reason for the absence of the vector of FD in other regions.

The dependence of FD on the vector (Caudwell, $1965 \mathrm{a})$ is of significance. The distribution of the vector is thus a determinant of where FD epidemics may occur outside SW France. The exception is Switzerland where $S$. titanus has been recorded but where Bois Noir and not FD, is reported (Bovey, 1972). The leafhopper is of little economic importance in the absence of FD (Schvester, Moutous and Carle, 1962).

Seasonal development: $S$. titanus overwinters as eggs, usually in the bark of grape-vine wood older than two years. Eggs hatch in the period from the end of spring to early summer and the mature adult emerges in late summer to early autumn (Schvester, Moutous, Bonfils and Carle, 1962; Carle, 1965a; Schvester, 1965a,b. Table 2 outlines the development of the leafhopper.

\section{TABLE 2}

Seasonal development of Scaphoideus titanus in Armagnac, SW France

\begin{tabular}{lll}
\hline & \multicolumn{1}{c}{ BEGIN } & \multicolumn{1}{c}{ END } \\
Eggs hatch: & 3rd week in May & early July \\
2nd instar: & 2nd week in June & late July \\
3rd instar: & 4th week in June & end July \\
4th instar: & 1st week in July & mid August \\
5th instar: & 2nd week in July & end August \\
Adult: & 4th week in July & late September \\
& & \\
\hline
\end{tabular}

S. titanus has only one generation per year and lives only on grape-vine (Schvester, Moutous and Carle, 1962).

Acquisition and transmission of $M L O$ : The vector of FD feeds in the vascular region of grape-vine leaves and stems, penetrating both phloem and xylem tissue (Vidano, 1964; Carle, 1965b). The combined acquisition, latent and inoculation period is 38 to 42 days, though in a few instances, 35 days have sufficed (Schvester, Carle et al, 1969).

Transmission is persistent; MLO multiply in the salivary glands to the vector and are transmitted during the life of the leafhopper (Schvester, Moutous and Carle, 1962; Schvester, Carle et al, 1969).

In the field, acquisition, hence transmission usually begins from June onwards, one month from the start of feeding of the first instar. Most transmission occurs later because the fourth and fifth instars and the adult are the most infective growth phases of the vector (Schvester, Carle et al, 1961).

\section{Laboratory Transmission:}

Several methods have been used in laboratory studies to transmit symptoms.

Leafhoppers: The natural vector of FD is easily collected from diseased vines and since the causal agents are not transmitted transovarially, it is easy to culture disease-free $S$. titanus in the laboratory (Caudwell, Kuszala et al, 1970).

In the field the leafhopper feeds only on grape-vine (Schvester, Moutous and Carle, 1962) but in the laboratory it could transmit MLO from diseased to healthy grape-vines, to broad bean (Vicia faba), Bellis sp., and to Chrysanthemum carinatum (Caudwell, Kuszala, et al, 1970).

Subsequent studies with other species of leafhopper were more successful (Caudwell \& Larrue, 1977). Euscelidius variegatus and Euscelis plebejus transmitted the FD pathogen to and from broad beans. They also transmitted disease to other herbaceous spp. including Vinca rosea.

E. Variegatus in particular, is easy to culture in the laboratory and is now used extensively in laboratory transmission studies (Caudwell et al, 1972b, 1977; Caudwell, Moutous et al, 1974; Caudwell \& Larrue, 1977, 1979).

A single infectious leafhopper is capable of transmitting disease to a broad bean host plant (Caudwell, 1977; Caudwell \& Larrue, 1979) but for hosts such as Lupinus angustifolius, Pisum sativum, and Vinca rosea, twenty infectious insects per plant are needed (Caudwell et al, 1973; Caudwell, 1977). This is why broad bean is the preferred host for laboratory studies of the vector-pathogen-host interactions of FD (Caudwell, 1977).

The incubation period of MLO in leafhoppers is 3 weeks and the pathogens of FD multiply in both the host and the insect.

Grafting: Graft transmission has been achieved only with difficulty (Caudwell, 1957, 1964; Caudwell \& Larrue, 1979). Diseased wood lacks the nutrient necessary for a successful graft union and will often die. It is therefore unsuitable for graft transmission trials.

For maximum transmission, symptomless tissue inoculated in the preceding summer is needed but since MLO do not invade all shoots on a yellows diseased grape-vine (Schvester, 1969), there is no means of ensuring all test wood is inoculated and 100\% transmission is never attained (Caudwell \& Schvester, 1970).

Most successful graft transmission of FD has been achieved by inserting indicator scion wood into diseased shoot tissue rather than the reverse combination (Caudwell, 1957; Gaertel, 1965). Transmission was obtained in at most, $40 \%$ of attempts.

Green grafting symptom-bearing tissue in the season of expression gave transmission rates of $10 \%$ to $40 \%$ (Caudwell \& Larrue, 1979). This little-tried technique is said to be easy (Hevin et al, 1978) but because of the low success rate, A. Caudwell (personal communication, 1985) no longer uses graft transmission to multiply the pathogen. 


\section{Control:}

Flavescence Dorée once in epidemic proportions in SW France (Caudwell \& Schvester, 1970), still causes severe crop loss in unsprayed vineyards but insecticide spray controls developed in 1963 have been most successful in reducing the population of the vector and thus in preventing the disease (Caudwell, Moutous et al, 1974).

The specificity of $S$. titanus to Vitis excludes the possibility of alternate weed hosts (Schvester, Moutous and Carle, 1962) and with the lack of transovarial transmission (Schvester, 1964), accounts for the effectiveness of vineyard vector control in reducing disease levels. Moreover, by spraying with insecticide in summer as a preventative treatment, it is possible to eradicate the disease from vineyards in subsequent years (Schvester, 1969, 1972).

Insecticide control of the first $S$. titanus instar is usually sufficient to control the leafhopper population (Carle, 1965a). Insecticide spraying over a large area is needed to prevent reinfestation in vineyards because, for maximum effectiveness, the district population of $S$. titanus must be reduced (Schvester, 1969).

The current insecticide spray recommendations for SW France are outlined in Table 3. Growers in Armagnac and Corsica are advised to use one of the follwing insecticides: parathion (ethyl or methyl), carbaryl, dimethoate and formothion.

\section{TABLE 3}

Recommended spray controls for Flavescence Dorée in SW France and Corsica Island

\begin{tabular}{lll}
$\begin{array}{l}\text { Spray } \\
\text { 1st }\end{array}$ & $\begin{array}{l}\text { Timing } \\
\text { January or March or } \\
\text { when hatching of } S . \\
\text { titanus is imminent. }\end{array}$ & $\begin{array}{l}\text { Use a strong insecti- } \\
\text { cide, e.g. parathion } \\
\text { in oil, as an ovicide. }\end{array}$ \\
\hline 2nd & mid June & $\begin{array}{l}\text { The second and } \\
\text { third treatments are }\end{array}$ \\
\hline 3rd & end of June & usually not needed \\
\hline 4th & mid July & \\
\hline 5th & early August & $\begin{array}{l}\text { The 5th and 6th } \\
\text { sprays are to control } \\
\text { leafhoppers from } \\
\text { adj }\end{array}$ \\
late August & $\begin{array}{l}\text { vineyards, if applic- } \\
\text { able. }\end{array}$
\end{tabular}

Usually three sprays are sufficient to reduce populations to a level for commercial control of the disease (Moutous, et al 1977). An ovicide spray, oleoparathion, is recommended for any time from January to March or when hatching of the eggs is imminent (Caudwell, Moutous et al, 1974; Moutous et al, 1977). A treatment against the nymphs of the first three instars is also recommended. This prevents infection of vines by leafhoppers that may have escaped the ovicidal treatment.
The Need for Quarantine Against Flavescence Dorée:

Caudwell and Larrue (1979) discuss this subject with respect to France, in detail. The following outline provides guidelines for other viticultural regions also.

To prevent introduction of the pathogen: Symptomless but inoculated dormant cuttings may be collected from diseased vineyards (Caudwell \& Schvester, 1970). If they survive and grow when planted in the following growing season, they will be diseased. However, the presence of $S$. titanus is required to transmit the pathogen before FD can spread from these vines.

Therefore, if the cuttings are planted in a vector-free area, the disease will not spread. If diseased cuttings carry eggs of the vector, the leafhoppers may hatch and feed on the young vine. However, eggs are rarely laid in the one-year-old wood that is selected as propagation material (Schvester, Moutous, Bonfils and Carle, 1962), and the diseased cuttings usually die. Transmission of FD in these circumstances is unlikely.

The possibility of promoting the spread of FD via propagation material is therefore only of commercial importance when $S$. titanus has been introduced before diseased cuttings.

Heat treatment of cuttings (Caudwell, 1966) and meristem culture are methods of obtaining disease-free propagation material if required (Caudwell \& Larrue, 1979).

To prevent the introduction of the vector: All epidemics in France have begun with the importation of the leafhopper vector (Caudwell, Moutous et al 1974; Caudwell \& Larrue, 1979). Regions with an environment favourable for its development are those both sufficiently warm in summer to allow maturation of the adult, hence egg laying to occur (Caudwell, Kuszala et $a l, 1970)$, and sufficiently cold to break diapause of the eggs (Caudwell, Moutous et al, 1974; Caudwell \& Larrue, 1979). However, S. titanus will survive only in regions where grape-vines are grown (Barnett, 1976), so non-viticultural regions are not at risk of supporting the vector, irrespective of their climates.

Because eggs of $S$. titanus may at times be carried on the bark of cuttings, in viticultural regions with suitable climates but without the vector, all imported cuttings should be planted initially under quarantine and the nurseries should be sprayed regularly with insecticide (Caudwell \& Larrue, 1979). In addition the vines should be spaced to allow penetration of light for symptom development, and to allow easy scrutiny of symptoms should they occur (Caudwell, 1965a).

However, it is probable that $S$. titanus has reached its natural limit of spread in France and as a result quarantine against its introduction into new regions of that country is not justified.

Flavescence Dorée too is thought to have reached the natural limit of its spread in France, despite the presence of the leafhopper outside these regions and the absence of formal quarantine measures. This is probably because of the recovery of many diseased vines and the difficulty in propagating diseased cuttings (Caudwell, 1964).

Also, many tolerant cultivars are probably symptomless carriers of the FD pathogen (Moutous, 1977) because infectious $S$. titanus are likely to have fed on and so transmitted MLO to them. The MLO may thus be 
present in areas in which the disease is not seen because susceptible cultivars are not grown. The subsequent arrival of a susceptible cultivar may then be mistakenly thought to signal the arrival of the disease organism in that region.

Therefore quarantines against the movement of propagation materials or the leafhopper, are not recommended in France.

\section{The Discovery of FD Outside Armagnac:}

In 1969 FD was found on Corsica Island (Boubals \& Caudwell, 1971) where the disease occurred more severely than in Armagnac. Yield losses of $80 \%-100 \%$ were common and affected vines died (Caudwell, Moutous et al, 1974).

The vector of FD was found in Italy in 1963 (Vidano, 1964, 1966). A graft transmissible disease with FD symptoms was found in 1973 (Belli et al, 1973; Osler et al, 1975) and in 1983 the vector was still found in abundance and the disease was actively spreading in vineyards (Belli et al 1984). Credi \& Babini (1984) recently reported that FD was occurring in other areas in Italy, and Granata (1982) and A. Caudwell (personal communication, 1985) reported FD in Sicily.

\section{BOIS NOIR}

A second member of the Grape-vine Yellows group, Bois Noir (BN), occurs in Central and Eastern France and in Switzerland (Caudwell, Moutous et al, 1974).

Although the incidence of disease increased considerably just prior to the increase of FD in SW France, at least some $\mathrm{BN}$ had been longstanding in these regions (Caudwell, 1964).

\section{Distribution and Spread:}

Bois Noir, unlike FD, spreads very slowly (Caudwell, 1965a) and remains localised. For example in a vineyard of Chardonnay for the five years from 1960 , the number of vines affected varied only between $11 \%$ and $15 \%$.

\section{Symptoms:}

The symptoms of BN are almost identical to those of FD though the disease appears two to three weeks later than FD and leaves colour less (Branas, 1956b; Gaertel, 1959; Caudwell, 1961a; Caudwell \& Schvester, 1970; Caudwell, Larrue et al, 1971). Black pustules occur at the base of shoots (Gaertel, 1959), at times extensively and more so than in FD diseased vines (Caudwell, 1961a). Diseased BN shoots also lignify more than FD affected shoots.

\section{Severity of Disease:}

The severity of $\mathrm{BN}$ within a vine seems unrelated to the previous level of disease (Caudwell, 1965a; Caudwell, Kuszala et al, 1972a). Usually only a few shoots are diseased on each vine although different shoots may be affected each year. Previously diseased vines, in apparently random seasons, are symptomless yet they may again be diseased or they may remain disease-free for several years.

Usually the crop loss from disease is not significant. However, diseased shoots blacken and die in winter, hence the name Bois Noir (black wood). They bear no fruit and yields are reduced. In addition, the continuity of disease within a vine debilitates its vigour and often a diseased vine will die (Caudwell, 1965a). For example, in one vineyard, $34 \%$ of diseased vines were affected for five consecutive years and $13 \%$ of these vines died within that period. In Switzerland, BN was seen in the late 1960's (Bovey, 1972) but, as in France, the disease is causing little concern.

\section{Cultivars Affected:}

The cultivars most susceptible to $\mathrm{BN}$ are Chardonnay, Poulsard, Amigne, and Gamay while others, e.g. Savagnin/Traminer, Gros Beclan, and Pinot Rouge are more tolerant of BN (Caudwell, 1961a). Chasselas and Pinot Noir are not affected.

\section{Cause of Disease:}

Little is known of the cause of BN. FD-like symptoms occur on Chardonnay and have been expressed experimentally on Baco 22A following graft transmission from BN diseased vines (Caudwell, 1964). Graft transmission of $\mathrm{BN}$, like that of $\mathrm{FD}$, is variable and only about $20 \%$ of grafted cuttings transmit disease (Caudwell, 1957, 1964). In these respects BN is nearly identical with FD and should be included in the Grapevine Yellows group. MLO may be the pathogen but they have not been found in $\mathrm{BN}$ diseased tissue and leafhoppers did not transmit $\mathrm{BN}$ from grape-vines (Caudwell, Larrue et al, 1971).

Rumbos et al, (1977), Rumbos (1978), and Rumbos and Biris (1979), found Rickettsia-like organisms (RLO) in young roots of diseased vines but the pathogenicity of these RLO has not been demonstrated.

\section{Association with a Vector:}

The leafhopper vector of FD, S. titanus, has been found in Switzerland (Baggiolini et al, 1968) but not in central and eastern France. The leafhoppers Euscelidius variegatus and Euscelis plebejus have been found in Burgundy vineyards and were shown to transmit FD to and from broad bean hosts (Caudwell, Kuszala et al, $1972 \mathrm{~b})$ but there is no further evidence of possible insect transmission of $\mathrm{BN}$.

Vineyards in Jura, Burgundy and Switzerland are however regularly sprayed with insecticide and it is possible that this controls potential vectors (Caudwell \& Larrue, 1979).

Rumbos (1978) found RLO in the nematode Xiphinema pachtaicum from the rhizosphere of diseased grape-vines, but the vector function of that nematode has not been demonstrated (Rumbos \& Biris, 1979).

It seems likely that any vector of $\mathrm{BN}$ is immobile because of the continuity of disease within individual vines, the more or less random distribution of disease within vineyards, and the very slow spread of disease. Vines adjacent to regularly diseased vines are often unaffected (Caudwell, Kuszala et al, 1972a) and the movement of a vector if any, is seemingly unrelated to previous sites of infection.

\section{GOLDGELBE VERGILBUNG}

The Vine Yellows disease that occurs in Germany is called Goldgelbe Vergilbung (GV) (Gaertel, 1965), or Vergilbungskrankheit (Mendgen, 1971), literally "golden yellow chlorosis". Although it caused serious loss in some vineyards of the Mosel Valley from 1950 to the 1970's it is not of major economic importance now (Gaertel, 1959, 1965; Mendgen, 1971; Kuppers et al, 1975).

The aetiology of disease is unresolved. 


\section{Distribution and Spread:}

Goldgelbe Vergilbung has been widespread in the Mosel, Saar, and Rhine River valleys (Gaertel, 1959) and recently was reported near Stuttgart (Hopp, 1982). It usually spreads slowly and vines often show symptoms for several years (Gaertel, 1959), though Kuppers et al, (1975) observed a significant increase in one vineyard in which diseased vines showed a marked recovery.

\section{Symptoms:}

Gaertel (1959, 1965), Mendgen (1971), and Rumbos and Biris (1979), consider the disease practically identical with FD except that more black pustules develop on $\mathrm{BN}$ shoots and leaves colour less in early spring. Also, budburst is not delayed in GV diseased vines.

\section{Severity:}

Yield reductions of up to $40 \%$ were observed in the 1970's (Kuppers et al, 1975) though losses peaked in the 1960's and were highest in warmest sites (Gaertel, 1965). Many bunches die and surviving bunches taint wine. Unlignified shoots die.

\section{Cultivars Affected:}

Riesling, Scheu-Rebe S88 (Sylvaner x Riesling) and Muller-Thurgau (Riesling $x$ Sylvaner) are the most susceptible although Chardonnay, Caesar, Gammay, and Aramon are also affected. Both own-rooted and vines on rootstocks are diseased (Gaertel, 1965).

Scheu-Rebe S88 though not a commercial cultivar, is used as an indicator.

\section{Cause of Disease:}

Goldgelbe Vergilbung is graft-transmissible but with difficulty (Gaertel, 1959, 1965). Phloem cells fluoresce and degenerate though Mendgen (1971) could not find MLO in diseased shoots. He found virus-like threads in the phloem of diseased but not healthy vines and considered the indirect proof of a MLO aetiology for FD (Giannotti, et al 1969) to be inappropriate.

Küppers et al, (1975) found RLO in thin sections of leaves from diseased and some healthy vines. They also found virus-like structures in deformed cells of diseased leaves but were unable to prove the pathogenicity of either of these organisms.

Later studies revealed high concentrations of RLO in the roots of diseased vines (Nienhaus \& Rumbos, 1979), and in nematodes (Xiphinema index) which transmitted the RLO (Rumbos \& Biris, 1979) and which were associated with diseased vines (Rumbos, 1978). The RLO have multiplied in chick embryos (Nienhaus et al, 1978) but their pathogenicity has not been tested.

There is thus some evidence that the causal agent is a procaryote and given the similarity of symptoms to $\mathrm{FD}$, it is appropriate to include GV in the Grape-vine Yellows group.

\section{Transmission:}

Grafting: Twenty to thirty percent of dormant grafted vines, showed unlignified and rubbery shoot growth (Gaertel, 1959, 1965). These vines later died. The frequency of transmission is low and variable like that for FD (Caudwell, 1957; Gaertel, 1959).

Leafhoppers: S. titanus has not been found in GV affected vineyards of Germany, (Gaertel, 1965) and though the leafhopper Empoasca flavescens is present, there is no evidence of insect vector transmission of disease.

\section{Control:}

There is no known control of GV and the routine insecticide spraying of German vineyards does not eradicate the disease as would be expected of such a spray programme against FD (Gertel, 1965).

\section{OTHER GRAPE-VINE YELLOWS DISEASES}

\section{In Australia:}

A yellows disease with FD-like characteristics in warmer districts and with $\mathrm{BN}$ and GV-like features in the cooler regions, has been described (Magarey \& Wachtel, 1986a,b). It is controlled effectively by tetracycline antibiotics but not penicillin (Magarey, Wachtel et al, 1983), and exhibits fluorescence of phloem in diseased shoot tissue (Magarey \& Wachtel, 1983). This implicates MLO as causal agents. Yield losses have been greatest on Chardonnay and Riesling (Emmett et al, 1983).

The similarity of these features with others in the Grape-vine Yellows group and with FD in particular, justify inclusion of the disease in that group and its name, Australian Grape-vine Yellows.

\section{In Greece:}

An epidemic disease with symptoms most similar to BN and GV (Rumbos \& Biris, 1979), was found in the early 1970's on the cultivars Rozaki, Italia, Cardinal, and Muscat of Hamburg (Kyriakopoulou \& Bem, 1973).

Bacteria or RLO were observed in the phloem of diseased but not healthy roots (Rumbos \& Biris, 1979) and antibiotic application may prevent symptom expression (Rumbos \& Biris, 1980) though published data are inconclusive. Inclusion of this disease in the Grapevine Yellows group is justified by its symptoms and epidemiology.

\section{In Israel:}

Symptoms typical of FD were observed in Israel in 1963 (Gaertel, 1965; Caudwell, Larrue et al, 1971) on the table grape cultivars, Pearl of Czaba, Madelaine Oberlin, Queen of the Vineyard, Muscat of Alexandria, and Caralicante. Ribier was less affected.

Symptoms were most severe in the hot valleys of north-east Israel (Tanne and Nitzany, 1973). Diseased vineyards were replanted and no symptoms have been seen since (E. Tanne - personal communication, 1981).

Graft transmission to Baco 22A was achieved though with difficulty and it is valid therefore to include this disease in the Grape-vine Yellows group. However, the leafhopper vector of FD S. titanus, has not been found in Israel and the aetiology of disease is unresolved (Tanne and Nitzany, 1973). Because of this, the disease should not be called FD.

\section{In Portugal:}

A disease called Enrolamento Foliar, literally "rolling of the leaves" has been reported on the cultivars Jaen and Borraçal from North Portugal (Mendonça et al, 1974). Symptoms are similar to both FD and Leaf Roll. Shoot growth is reduced, and leaves yellow or redden and roll downwards. Frequently shoots do not harden properly but bunches survive. 
Diseased vines contained pleomorphic structures that resembled MLO. Heat-treated diseased vines did not. Mendonça et al, (1974) concluded it was possible these mycoplasma-like structures were the pathogens and that because of this and the symptomatology, the disease could be included in the Grape-vine Yellows group proposed by Caudwell, Larrue et al, (1971). Though Caudwell, (1980a) did not include this disease in his brief review of Grape-vine Yellows, the conclusion of Mendonça et al, appears justified.

\section{In Roumania:}

A yellows disease with FD-like symptoms and affecting few widely scattered vines, has been described and referred to as FD (Rafalia and Costache, 1970). Gaertel, (1974) referred to it as BN when he described a similar disease in Hungary.

Its inclusion in Grape-vine Yellows is based on the likeness of its symptoms to FD.

\section{In U.S.A.:}

A yellows disease known as Leaf Curl and Berry Shrivel (LCBS) was reported from two De Chaunac vineyards in New York State, U.S.A. (Uyemoto, 1974). The main symptoms were leaf curl and berry shrivel and were considered very similar to FD (Uyemoto, 1974; Uyemoto et al, 1977, 1978). The disease spread slowly despite the presence of $S$. titanus, native to that area and when affected vines were removed, no further symptoms were seen.

The cause of LCBS is not known and the relationship of this disease to other members of the Grape-vine Yellows group is unresolved. Its inclusion in the Yellows group is justified mostly by similarity of symptoms to FD and although reported as FD by some (Van Heerden, 1978), this has not been established.

\section{In Chile:}

A yellows disease of grape-vines known as Amarilliamento de Elqui, occurs in a small region of the d'Elqui Valley (Caudwell, Larrue et al, 1971; Caudwell, 1980b). Symptoms are similar to FD but diseased shoots are not stunted, they lignify and all leaves may fall (Caudwell, 1980b). The disease spreads slowly from distinct centres of infection in vineyards. S. titanus has not been found and the infectious nature of the disease has not been demonstrated.

This disease, which Gaertel referred to as FD (Caudwell, Larrue et al, 1971, is included as a member of the Grape-vine Yellows group on the basis of disease symptomatology and a limited understanding of its epidemiology. This classification is best considered temporary until more is known of its aetiology.

\section{In France:}

$S$. titanus the vector of FD, transmits a yellows disease of beans, $\varphi$-yellows, to grape-vines where it shows symptoms identical to FD (Caudwell, Larrue et al, 1971; Caudwell, Moutous et al, 1974). This and its transmission by other in vitro vectors of FD (A. Caudwell - personal communication, 1985) justify its inclusion in the Grape-vine Yellows group (Caudwell, Larue et al, 1971).

\section{In New Zealand:}

Bovey et al, (1980) reported an FD-like grape-vine yellows disease in New Zealand and called it FD, but this report has not been confirmed.

\section{DIAGNOSIS OF GRAPE-VINE YELLOWS}

Despite the lack of formal proof of pathogenicity, the diseases of the Grape-vine Yellows group bear many similarities. Some differences that have been noted, may be caused by the differing climates of the respective regions and countries.

For example, the difference between symptoms of FD and BN may be caused by the lower temperatures, viz. $2-3^{\circ} \mathrm{C}$, (Smart \& Dry, 1980) and shorter growing season of the northerly regions of Burgundy and Jura, compared to those of Armagnac in the south. A. Caudwell (personal communication, 1985) considers BN shoots lignify more than FD affected shoots because disease is expressed later in the cooler, northerly regions.

Disease severity is the main difference between FD and BN (Caudwell, 1965a). FD debilitates vines but $\mathrm{BN}$ rarely affects them severely and vines affected by FD show a marked recovery while those with $\mathrm{BN}$ are diseased regularly (Caudwell, 1957; Caudwell, Kuszala et al, 1972a; Caudwell, Moutous et al, 1974). FD is epidemic, it spreads quickly and is transmitted in vivo by $S$. titanus while BN is endemic, spreads slowly and has no known vector (Caudwell, 1965a, 1983). These differences may be explained by differences in cultivar susceptibility and occurrence.

For instance, Baco 22A is common in Armagnac and very susceptible to FD, but is not grown in Burgundy. Pinot Noir is susceptible to BN and is common in Burgundy but not in Armagnac. However, this cultivar is susceptible to FD in Italy, and Chardonnay is susceptible to both FD and $\mathrm{BN}$.

An additional cause of the differences may be the combined effect of lower temperature and regular insecticide spraying in Burgundy; this may account for the absence of $S$. titanus in that region (Schvester, 1962; Caudwell \& Larrue, 1979). The nature of these differences and the possible reasons for them probably apply to other features of the two diseases and to other members of the Grape-vine Yellows group.

Despite these differences, Grape-vine Yellows diseases have at least two diagnostic features in common. First their symptoms, and second the possibility that they are caused by procaryotic organisms (Caudwell, 1980a). A lack of information about some members prevents their comparison and diagnosis. For FD the aetiology of disease is well known. For BN, GV and others, though it is understood in part, it is unresolved.

More definitive identification of the causal agent, epidemiology, diagnosis, and thus taxonomy of Grapevine Yellows diseases must await further investigation and, in some instances, further technological development (Nienhaus \& Sikora, 1979). As an example, the observation and serological identification of procaryote organisms in grape-vines is at present, achieved only with difficulty.

Nevertheless consistency in the first and at least one other of the following features of Grape-vine Yellows diseases, is currently acceptable to identify a disease as a member of the Grape-vine Yellows group:

1. Symptoms: On grape-vine symptoms are identical with or similar to those of FD (e.g. Caudwell, 1957, 1964; Gaertel, 1959; Schvester, 1963; Caudwell \& Schvester, 1970; Bovey et al, 1980). 
2. Graft transmission: Infectivity can be graft-transmitted to Baco 22A causing symptoms typical of FD; transmission rates are low and variable depending on the choice of material (Caudwell, 1964; Caudwell \& Larrue, 1979).

3. Insect transmission: Transmission is by leafhoppers (Caudwell, 1980a). Transmission by $S$. titanus from grape-vine and by $E$. variegatus from broad bean is specific evidence of FD (Schvester, Carle et al, 1963b; Caudwell, 1965a).

4. Occurrence of a procaryote: Electron microscopy may reveal MLO or RLO associated with diseased but not healthy phloem tissue (Caudwell, Kuszala et al, 1973; Caudwell, 1980a). This observation can be supplemented and assisted by fluorescence microscopy to detect fluorescent and necrotic phloem cells initially (Carle, 1965b,c).

5. Efficacy of antibiotic: Oxytetracycline but not peni- cillin is effective against MLO; penicillin acts against ROLO (McCoy, 1979; Nienhaus \& Sikora, 1979). Remission or prevention of symptoms following antibiotic treatment of vines is a useful aetiological character and has potential for successful application with more members of the Grape-vine Yellows group.

In addition, two features provide supportive evidence:

1. Heat therapy - infectivity is destroyed by short periods at high temperature (Caudwell, 1966; McCoy, 1979).

2. Other - mechanical transmission and cultivation of a pathogen is impossible or is achieved temporarily with difficulty (Caudwell, Kuszala et al, 1973; Caudwell, Kuszala and Larrue, 1974 a to d; Saglio \& Whitcomb, 1979).

\section{LITERATURE CITED}

BAGGIOLINI, M., CANEVASCINI, V., CACCIA, R., TENCALLA, Y. and SOBRIO, G., 1968. (The presence in vineyards in the Ticino of a Neartic Cicadellid new to Switzerland, Scaphoideus littoralis, Ball. (Hom., Jassidae), a potential vector of golden flavescence.) Bull. Soc. Entomol. Suisse, 40 (3-4), 270-275. (Fr, en in RAE A (1969) 57: 1478)

BARNETT, D.E., 1976. A revision of the Neartic species of the genus Scaphoideus (Homoptera: Cicadellae). Trans. Am. Ento Soc. 102(4): 484-593. (Abst. RAE A (1977) 65(12): 6414)

BELLI, G., FORTUSINI, A., OSLER, R., and AMICI, A., 1973. (Presence of a "Flavescence dorée" type disease in vineyards of Oltrépo Pavese.) 5th Meeting ICVG, Salice Terme, Italy. Sept. 1973. Riv. Patol. Veg. Ser. 4(1973) 9(3). Suppl: 50-56. (It, en in RPP (1975) 54(3): 941g)

BELLI, G., RUI, D., FORTUSINI, A., PISSOLI, L., and TORRESIN, G., 1984. (Occurrence of the leafhopper vector (Scaphoideus titanus) and further spreading of flavescence dorée in northeastern Italy). Vignevini, Bologna 11(9): 23-27 (It, en) in: Vitis 24 (1985) 1:14. Abst. 1H4

BONFILS, J., and SCHVESTER, D., 1960. (The leafhoppers (Homoptera Auchenorrhyncha) and their relationship with vineyards in south-western France.) Ann. Apiph. 11(3): 325-336. (Fr, en in RAE A (1962) 50: 372)

BOUBALS, D., and CAUDWELL, A., 1971. (An epidemic of yellows in vineyards of Corsica: probably Flavescence dorée.) Prog. Agric. et Vitic. 88(19): 355-364. (Fr)

BOVEY, R., 1970. Record of symptoms of Flavescence dorée and transmission of corky bark from a plant with Flavescence dorée symptoms in Switzerland (Abst.). 4th Meeting ICVG, Colmar, France. June 1970. In ref. 45.

BOVEY, R., 1972. (Occurrence of Flavescence dorée in Switzerland and its possible relation to "corky bark".) 4th Meeting ICVG, Colmar, France. June 1970. Ann. Phytopathol., No. hors serie: pp. 167-170. (Fr, en)

BOVEY, R., GAERTEL, W., HEWITT, W.B., MARTELLI, G.P. and VUITTENEZ, A., 1980. Diseases caused by intracellular Procaryotes (Mycoplasma-like and Rickettsia-like micro-organisms). pp. 57-61, 124-33 in "Virus and Virus-like Diseases of Grape-vines. Colour atlas of symptoms". Editions Payot Lausanne. $184 \mathrm{pp}$

BRANAS, J., 1956a. (The "disease of Baco 22A".) Prog. Agric. et Vitic. 45-46: 289-97. (Fr)

BRANAS, J., 1956 b. (The "disease of Chardonnay".) Prog. Agric. et Vitic. 47-48: 320-25. (Fr)

CARLE, P., 1965 a. (Tests of insecticides in the field against Scaphoideus littoralis (Homopt., Jassidae).) Phytiat. - Phytopharm. 14(1): 29-38. (Fr, en in RAE A (1966) 54 p. 458)

CARLE, P., 1965 b. (The fluoroscopy of the histological symptoms of Golden Flavescence of the vine. Its application to the rapid detection of early lesions in susceptible varieties (Baco 22A).) Ann. Epiph. 16 No. hors serie I, pp. 73-85-(Fr, en.)
CARLE, P., 1965 c. Observation and detection by fluorescence microscopy of the internal symptoms in tissues of flavescence dorée-diseased grapes. Proc. Int'l Conf. on Virus and Vector on Perennial Hosts. Davis, Univ. Calif. Div. Ag. Sci., pp. 282-286.

CAUDWELL, A., 1956. (Research and observation on the disease of Baco 22A in 1955 and 1956.) Reveil Landais, 107, $2^{\mathrm{c}}$ quinz. Oct., 2-3 (Fr)

CAUDWELL, A., 1957. (A two year study on the Flavescence dorée, a new serious disease of vine.) Ann. Amelior. Plantes (Paris) 4, 359-393. (Fr, en) and Terre d'Oc. 41: 448-468.

CAUDWELL, A., 1961 a. (A study of the disease Bois noir of the vine: a comparison with Flavescence dorée.) Ann. Epiph. 12(3): 241-262. (Fr, en)

CAUDWELL, A., 1961 b. (The phenomenon of recovery of Flavescence Dorée of the vine.) Ann. Epiph. 12(3): 347-354. (Fr)

CAUDWELL, A., 1964. (Identification and study of Golden Flavescence, a new virus infection of the vine. Study of localisation of symptoms and recovery in virus-infected plants.) Ann. Epiph. 15 No. hors serie I, pp 1-193. (Fr, en)

CAUDWELL, A., 1965 a. (The biology of Flavescence Dorée and the ground work for preventative measures.) Ext. Bull. Tech. Information Ingenieurs services Agricoles No. 198: 1-12. (Fr)

CAUDWELL, A., 1965 b. Reactions of host plants to Flavescence dorée virus. Proc. Int. Conf. Virus and Vector on Perennial Hosts, Davis, Univ. Calif. Div. Ag. Sci., pp. 126-135.

CAUDWELL, A., 1966. (Inhibition of the Flavescence Dorée virus in vivo by means of heat treatment.) Ann. Epiph. 17 No. hors serie. pp. 61-66. (Fr, en)

CAUDWELL, A., 1977. (Statistical aspects of infectivity tests for Yellows diseases and viruses persistently transmitted. Advantages of broad bean (Vicia faba) as a test plant for Yellows diseases.) Ann. Phytopathol. 9(2): 141-159. (Fr, en)

CAUDWELL, A., 1978. (Etiology of yellows of plants.) PhytomaDefense des cultures. No. 294 (Janvier): 5-9, with correction in No. 294 (Fevrier): 38, (1978) (Fr)

CAUDWELL, A., 1980 a. Current approaches to the aetiology of grape-vine diseases associated with mycoplasma- or rickettsialike organisms (MLO or RLO). Proc. 7th Meeting ICVG. Vineland, Ont., Canada; Agriculture Canada. pp. 159-169.

CAUDWELL, A., 1980 b. L'amarilliamento de Elqui, new yellows disease of vine in Chile. Proc. 7th Meeting ICVG. Vineland, Ont., Canada; Agriculture Canada. pp. 9-13.

CAIJDWELL, A., 1981. (Flavescence aorée of grape-vines in France.) Phytoma (Paris) No. 325: 16-19. (Fr, en in RPP (1982) 61(5): 2373)

CAUDWELL, A., 1983. (On the origin of mycoplasm (MLU)-induced yellows diseases in plants, the example of grape-vine yellows). Agronomie 3(2): 103-111.

CAUDWELL, A., BACHELIER, J.-C., KUSZALA, C., and LARRUE, J., 1977. (A useful holder for microinjections of the 
leafhoppers during infectivity tests.) Ann. Phytopathol. 9(4): 521-523 (Fr, en)

CAUDWELL, A., GIANNOTTI, J., KUSZALA, C., and LARRUE, J., 1971. (Study of the role of mycoplasma-type particles in the aetiology of Flavescence dorée in vines. Cytological examination of diseased plants and infectious leafhoppers.) Ann. Phytopathol. 3(1): 107-123 (Fr, en)

CAUDWELl, A., KUSZALA, C., BACHELIER, J.-C., and LARRUE, J., 1970. (Transmission of Flavescence dorée of vines to herbaceous plants by the prolongation of the time during which Scaphoideus littoralis Ball (Cicadellidae), can be used and the study of its survival on a large number of plant species.) Ann. Phytopathol. 2(2): 415-428. (Fr, en)

CAUDWELL, A., KUSZALA, C., and LARRUE, J., 1973. (Practicable methods for the study of Flavescence dorée of grapevines.) 5th Meeting ICVG, Salice Terme, Italy, Sept. 1973. Riv. Patol. Veg. Ser. 4 (1973) 9(3): 269-276. (Fr, en)

CAUDWELL, A., KUSZALA, C., and LARRUE, J., 1974 a. (Approach to the survival and culture of the agent (MLO) of a yellows disease, Flavescence dorée of grape-vine, by pathogenicity tests.) Compt. Rend. Hebd. Seances l'Acad. des Sci. D, 279(6): 523-525. (Fr, en in RPP (1975) 54(7): 2915)

CAUDWELL, A., KUSZALA, C., and LARRUE, J., 1974 b. (In vitro maintenance of the mycoplasma (MLO) type pathogenic agent of Flavescence dorée of grape-vine.) Ste Biologie Poitiers Seance, 26 Oct. 1974. (Fr, en in "The viroses and virus-like diseases of the grape-vine. A bibliographic report 1971-1978". W.B. Hewitt and R. Bovey. Vitis 18 (1979): 316-376. Abst. 1582)

CAUDWEll, A., KUSZALA, C., and LARRUE, J., 1974 c. (A study of the pathogenic agent of a yellows: Flavescence dorée of grape-vine.) Proc. Congr. Int. on the mycoplasmes de l'Homme des animaux, des vegetaux et des insects, Bordeaux, Sept. 1974. Resumé des communications, p. 11. (Fr, en in Vitis 18 (1979): 316-376. Abst. 1581)

CAUDWELL, A., KUSZALA, C., and LARRUE, J., 1974 d. (On the in vitro culture of the infective agents causing plant yellows (MLO).) Ann. Phytopathol 6(2): 173-190. (Fr, en)

CAUDWEll, A., KUSZALA, C., and LARRUE, J., 1976. Progress in the culture of the etiologic agent, type mycoplasma, of the Flavescence doreé of grapes. Proc. Soc. Gen. Microbiol. III 3: 154

CAUDWEll, A., KUSZAla, C., LARRUE, J., and BACHELIER, J.-C., 1972 a. (Responsibility of an aerial vector in the epidemiology of Black Wood of the vine. Study of the existence of sensitive and tolerant plants explaining the permanence of the disease on the same plants.) 4th Meeting ICGV, Colmar, France, 16th-18th June 1970. Ann. Phytopathol. No. hors serie, 171-180. (Fr, en)

CAUDWEll, A., KUSZALA, C., LARRUE, J., and BACHELIER, J.-C., 1972 b. (Transmission of Golden Flavescence from Vicia faba to Vicia faba by Cicadelles of the genera Euscelis and Euscelidius. Possible intervention of these insects in the epidemiology of Black Wood in Burgundy.) 4th Meeting ICGV, Colmar, France, 16th-18th June 1970. Ann. Phytopathol. No. hors. serie, 181-189. (Fr, en)

CAUDWELL, A., and LARRUE, J., 1977. (The production of healthy and infectious leafhoppers for infectivity tests of yellows diseases of plants associated with mollicutes. Breeding of Euscelidius variegatus $\mathrm{KBM}$ and egg laying on polyurethane foam.) Ann. Zool. Ecol. anim. 9(3): 443-456. (Fr, en)

CAUDWELL, A., and LARRUE, J., 1979. (Examination of the problem of Flavescence Dorée as part of health selection of grape-vine wood and plants.) Prog. Agric. et Vitic. (1st March 1979) 96(6): 128-134. (Fr, en in RPP (1980) 59(10): 4704)

CAUDWELl, A., LARRUE, J., KUSZALA, C., and BACHELIER, J.-C., 1971. (Plurality of Vine Yellows Diseases.) Ann. Phytopathol. 3(1): 95-105. (Fr, en)

CAUDWELL, A., LARRUE, J., MOUTOUS, G., FOS, A., and BRUN, P., 1978. (Leafhopper transmission of the Corsican yellows disease of the grape-vine. Identification with Flavescence dorée. I - Investigations made outside Corsica.) Ann. Zool. Ecol. Animale (Paris) 10(4): 613-625. (Fr, en in Vitis (1979) 18(4): 404)

CAUDWELL, A., MEIGNOZ, R., KUSZALA, C., SCHNEIDER, C., LARRUE, J., FLEURY, A., and BOUDON, E. 1981. (Observation of the pathogenic agent (MLO) of Flavescence dorée of grape-vine, in liquid medium by immunosorbant electromicroscopy (ISEM).) Prog. Agric. et Vitic. No. 24: 835-838. (Fr)

CAUDWELL, A., MEIGNOZ, R., KUSZALA, C., SCHNEIDER, C., LARRUE, J., FLEURY, A., and BOUDON, E. 1982. (Immunological purification and ultramicroscope observation in liquid medium of the pathogen (MLO) of a plant yellows, grape-vine Flavescence dorée.) Compt. Rend. Seances de l'Acad. d'Agric. de France. 68(6): 407-415. (Fr, en)

CAUDWELl, A., MOUTOUS, G., BRUN, P., LARRUE, J., FOS, A., BLANCON, G., and SCHICK, J.P., 1974. (The epidemics of Flavescence dorée in Armagnac and in Corsica, and new understandings in the control of the vectors by treatment with ovicides in winter.) Bull. Techn. Inform. 294: 783-794. (Fr)

CAUDWELL, A., and SCHVESTER, D., 1970. Flavescence dorée, In: Frazier, N.W. (Ed.): Virus diseases of small fruits and grapevines. (A handbook). Univ. Calif., Div. Agric. Sci., Berkeley, Calif., U.S.A. pp. 201-207.

CREDI, R., and BABINI, A.R., 1984. (Outbreak of grape-vine yellows in the region of Emilia-Romagna). Vignevini, Bologna 11(3): 35-39 in: Vitis 23 (1984) 3:20. Abst. 3H44.

EMMETT, R.W., PYWELL, M., HOLLAND, S.A., MAGAREY, P.A., and WACHTEL, M.F., 1983. Australian Vine Yellows III. Effect on the yield of two grape-vine cultivars - preliminary results. page 114 in: Abstracts of Papers, 4th Int'l Cong. Pl. Path., Univ. Melb., Aust., Aug 17-24. Abst. 453, 273 pp.

GAERTEL, W., 1959. (The "Flavescence dorée" or "Disease of Baco 22A". Report of a study trip to France 10th-30th August, 1958.) Weinberg and Keller 6: 295-311. (De)

GAERTEL, W., 1965. (Investigation of the appearance and behaviour of Flavescence dorée in Mosel and Rhine.) Weinberg and Keller 12: 347-376. (De, en, fr)

GAERTEL, W., 1974. (Annual report for 1972, Federal Biological Institute for Agriculture and Forestry at Berlin and Brunswick. Institute for Grape-vine Diseases, Berkastel - Kues.) p. 91. (De), in RPP (1975) 54(3): 651.

GIANNOTTI, J., CAUDWELL, A., VAGO, C. and DUTHOIT, J.L., 1969. (Isolation and purification of micro-organisms of the mycoplasma type from vines infected with golden flavescence.) C.r. Hebd. Seances. Acad. Sci. 268: 845-847. (Fr), in RAE A(1971) 59:593

GOHEEN, A.C., 1977. Virus and virus-like diseases of grapes. Proc. Symposium Viruses in Fruit Crops, Louisiana State Uni., Baton Rouge, Aug. 1976. Hort. Sci. 12(5): 465-469.

GRANATA, G., 1982. (Decline and yellows of grape-vine.) Informatore Fitopatologico. 32(7/8): 18-20. (It, en), in RPP (1983) 62(1): 294

HEVIN, M., MOUTOUS, G., FOS, A. and RIVES, M., 1978 (Transmission of Flavescence dorée by green grafting is easy and suggests that this disease is distinct from Corky Bark.) Proc. 6th ICVG, Cordoba, Spain. Sept. 1976. Monografias Inst. Nacional Investigaciones Agrarias, No. 18. Minst. de Agricult., Madrid, pp. 227-229. (Fr, en, es)

HOPP, H., 1982. (Grape-vine yellows of the "black wood" type now occurring also in the viticultural sites of southern Baden.) Bad. Winzer (2): 47-53 in: Vitis 21(1982) 2: 190.

KUPPERS, P., NIENHAUS, F. and SCHINZER, U., 1975. Rickettsia-like organisms and virus-like structures in a yellows disease of grape-vines. Z. Pflanzenkrankh. Pflanzensch. 82(3): 183-187.

KYRIAKOPOULOU, P.E. and BEM, F.P., 1973. Some virus diseases of cultivated plants noticed in Greece during 1971 and 1972. A Symposium of Geotechnical research, Athens. Jan. 1973. Rept. No. 102. (Gr, en in "The viroses and virus-like diseases of the grape-vine. A bibliographic report. 1971-78". W.B. Hewitt and R. Bovey. Vitis 18 (1979): 316-376. Abst. 1772).

LEVADOUX, L., 1955. (The sanitary state and selection of Baco 22A.) Agriculture. No. 172: 257-259. (Fr) in ref. 19.

McCOY, R.E., 1979. Mycoplasmas and yellows diseases, in "The Mycoplasmas". Vol. III, Plant and Insect Mycoplasmas. pp. 229-264 Edited by R.F. Whitcomb and J.G. Tully (Academic Press, New York).

MAGAREY, P.A. and WACHTEL, M.F., 1983. Australian Vine Yellows I. Inference of a mycoplasma-like aetiology for a new disease of Australian Grape-vines. P. 118 in: Abstracts of Papers, 4th Int'l Cong. Pl. Path., Univ. Melb., Aust., 17-24 Aug., Abst. 470. 273pp.

MAGAREY, P.A. and WACHTEL, M.F., 1986 a. Grape-vine yellows, a widespread, apparently new disease in Australia. Plant Disease 70: (in press). 
MAGAREY, P.A. and WACHTEL, M.F., 1986 b. A review of the present status of Australian Grape-vine Yellows. Agricultural Record 12(17): (in press).

MAGAREY, P.A., WACHTEL, M.F., EMMETT, R.W., PYWELL, M., and HOLLAND, S.A., 1983. Australian Vine Yellows II. Implications from the effect on disease of antibiotic type, concentration and date of application. P. 118 in: Abstracts of papers, 4th Int'l Cong. Pl. Path., Univ. Melb., Aust., 17-24 Aug., Abst. 471. 273pp.

MENDGEN, K., 1971. (Studies on a yellows disease of grape-vines along the Rhine, Mosel and Saar.) Weinberg and Keller 18(8/9): 345-431. (De, en, es, fr)

MENDONCA, A. de V.E., SEQUEIRA, O.A. de, and MOTA, M., 1974. Mycoplasma-like structures extracted from Vitis vinife$r a \mathrm{~L}$. and observed by the negative staining technique. Agronomia Lusit. 35(3): 277-282.

MOUTOUS, G., 1977. (Definition of the symptoms of 'golden flavescence' on vinestock varieties. Study of their susceptibility.) Revue de Zoologie Agricole et de Pathologie Vegetale. 76(3): 90-98. (Fr, en), in RAE A (1978), 66(12): 6082.

MOUTOUS, G., FOS, A., BESSON, J., JOLY, E. and BILAND, P., 1977. (Results of ovicide tests against Scaphoideus littorialis Ball., a leafhopper vector of golden flavescence.) Revue de Zoologie Agricole et de Pathalogie Vegetale. 76(2): 37-49. (Fr, en), in RAE A (1978), 66(6): 3184.

NIENHAUS, F. and RUMBOS, I., 1979. Rickettsia-like organisms in grape-vines with yellows disease in Germany. Proc. 6th Meeting, ICVG, Cordoba, Spain, Sept. 1976. Monografias Inst. Nacional Investigaciones Agrarias No. 18. Minist. de Agricult., Madrid, pp. 223-226. In: "The Viruses and virus-like diseases of the grape-vine. A bibliographic report. 1971-78". W.B. Hewitt and R. Bovey. Vitis 18(1979): 316-376. Abst. 1887.

NIENHAUS, F., RUMBOS, I. and GREUEL, E., 1978. First results in the cultivation of Rickettsia-like organisms of yellows diseased grape-vines in chick embryos. Z. Pflanzenkrankh. Pflanzensch. 85(2): 113-117.

NIENHAUS, F. and SIKORA, R.A., 1979. Mycoplasmas, spiroplasmas, and rickettsia-like organisms as plant pathogens. Annual Review Phytopathology. 17: 37-58.

OSLER, R., FORTUSINI, A. and BELLI, G., 1975. (Presence of Scaphoideus littoralis in vineyards of Oltrepo pavese affected by a disease of the type "flavescence dorée".) Informatore Fitopatologico. 25(6): 13-15. (It, en), in RPP (1976), 55(3): 1381.

RAFALIA, C. and COSTACHE, M., 1970. The golden flavescence (Flavescence dorée), a new disease of grape-vine in Roumania. An. Inst. Cercet. Protectia Plant. 6: 151-156.

RUMBOS, I., 1978. (Investigation into Rickettsia-like Organisms in yellows diseased grape-vines (Vitis vinifera L.).) Diss. Univ. Bonn., 146 pp. (De), in: "The viroses and virus-like diseases of the grape-vine. A bibliographic report. 1971-78". W.B. Hewitt and R. Bovey. Vitis 18(1979): 316-376. Abst. 1988.

RUMBOS, I., and BIRIS, D., 1979. Studies on the aetiology of a yellows disease of grape-vines in Greece. Z. Pflanzenkrankh. Pflanzensch. 86(5): 266-273.

RUMBOS, I. and BIRIS, D., 1980. Preliminary report of the control of a yellows disease of grape-vines in Greece. Proc. 5th Congr. Un. Phytopath. Mediterr., Patras, Greece. 21-27th Sept. 1980. The Hellenic Phytopath Soc., Athens, Greece, pp. 57-59.

RUMBOS, I., SIKORA, R.A. and NIENHAUS, F., 1977. Rickettsia-like organisms in Xiphinema index Thorne and Allen found associated with yellows disease of grape-vines. Z. Pflanzenkrankh. Pflanzensch. 84(4): 240-243.

SAGLIO, P.H.M. and WHITCOMB, R.F., 1979. Diversity of wallless procaryotes in plant vascular tissue, fungi, and invertebrate animals, in "the Mycoplasmas". Vol. III. Plant and Insect Mycoplasmas. pp. 1-36. Edit by R.F. Whitcomb and J.G. Tully. (Academic Press, New York).

SCHVESTER, D., 1962. (Plans for the control of golden flavescence by the destruction of its vector: Scaphoideus littoralis.) Revue Zool. Agric. Appl. 61(10-12): 135-143. (Fr), in RAE A (1964), 52: 85 .

SCHVESTER, D., 1963. (Origin of the symptoms and characteristics of the spread of golden flavescence of vines.) Ann. Epiphyt. 14(3): 167-174. (Fr, en), In RAE A (1964) 52: 247.
SCHVESTER, D., 1964. (The Cicadellids and 'Flavescence dorée' of vines in southwestern France.) Weinberg and Keller, 11(7): 371-382. (De).

SCHVESTER, D., 1965a. (Cicadellids and flavescence dorée of the vine.) Bull. Tech, Inf. ISA 198, p. 389-394. (Fr), in ref. 44.

SCHVESTER, D., 1965b. The bionomics of specific vectors of plant viruses. Phloem feeding insect vectors (with special reference to Scaphoideus littoralis Ball. vector of the Flavescence dorée). Proc. Int'l. Conf. on Virus and Vector on Perennial Hosts. Davis, Univ. Calif. Div. Ag. Sci. pp. 107-116.

SCHVESTER, D., 1969. (Insecticide treatments and the recovery of vines affected by golden flavescence.) Annls. Zool. Ecol. Anim. 1(4): 467-494. (Fr, en, de), in RAE A (1971) 59: 4047.

SCHVESTER, D., 1972. (Vine Cicadellids.) OEPP/EPPO Bull. 1(3): 37-42. (Fr, en), in RAE A (1973) 61(3): 762.

SCHVESTER, D., CARLE, P. and MOUTOUS, G., 1961. (On the transmission of golden flavescence of vines by a Cicadellid.) C.R. Acad. Agric. Fr. 47(18): 1021-1024 and Proc. Agr. et Vitic. 79(5): 126-131. (Fr), in RAE A (1963) 51: 635.

SCHVESTER, D., CARLE, P. and MOUTOUS, G., 1963a. (On the transmission of golden flavescence of the vine by Scaphoideus littoralis Ball.) C.R. Acad. Agric. Fr. 49(2): 139-144. (Fr), in RAE A (1964) 52:501.

SCHVESTER, D., CARLE, P. and MOUTOUS, G., 1963b. (Transmission of golden flavescence of vines by Scaphoideus littoralis Ball. (Homopt., Jassidae). Experiments performed in 1961.) Ann. Epiphyt. 14(3): 175-198. (Fr, en), in RAE A (1964) 52: 247.

SCHVESTER, D., CARLE, P. and MOUTOUS, G., 1967. (Tests on the susceptibility of vine stocks to golden flavescence with inoculation by means of Scaphoideus littoralis Ball.) Annls. Epiphyt. 18 no. hors serie pp. 143-150. (Fr, en, de), in RAE A (1968) 56: 2471.

SCHVESTER, D., CARLE, P. and MOUTOUS, G., 1969. (New data on the transmission of golden flavescence of vines by Scaphoideus littoralis Ball.) Annls. Zool. Ecol. Anim. 1(4): 445-465, 493-494. (Fr, en, de), in RAE A (1971), 59: 4046.

SCHVESTER, D., MOUTOUS, G., BONFILS, J. and CARLE, P., 1962. (A biological study of vine Cicadellids in southwestern France.) Ann. Epiphyt. 13(3): 205-237. (Fr, en), in RAE A (1963) 51:548.

SCHVESTER, D., MOUTOUS, G. and CARLE, P., 1962. (Scaphoideus littoralis Ball. (Homopt. Jassidae) a Cicadellid vector of the golden flavescence of vines.) Rev. Zool. agric. 61(10-12): 118-131. (Fr), in RAE A (1964) 52: 85.

SMART, R. and DRY, P.R., 1980. A climatic classification for Australian viticultural regions. The Australian Grapegrower and Winemaker No. 196. Annual Technical Issue, April 1980, pp. 8, $10,16$.

TANNE, E. and NITZANY, F.E., 1973. Virus diseases of grapevine in Israel. Vitis 12(3): 222-225.

UYEMOTO, J.K., 1974. A new disease affecting the grape-vine variety De Chaunac. Proc. Amer. Phytopath. Soc. 1: 146 (Abstr.)

UYEMOTO, J.K., CUMMINS, J.R. and ABAWI, G.S., 1977. Virus and virus-like diseases affecting grape-vines in New York vineyards. Amer. J. Enol. Viticult. 28: 131-136.

UYEMOTO, J.K., MARTELLI, G.P., WOODHAM, R.C., GOHEEN, A.C., and DIAS, H.F., 1978. Set No. 1, Grape-vine (Vitis) Virus and Virus-like Diseases, 29 p. (with 100 slides) in "Plant Virus Slide Series". Edited by O.W. Barnett and S.A. Tolin (Clemson University, Clemson, SC).

VAN HEERDEN, H.P., 1978. Plant protection and phytosanitary control in Southern Africa. Paper read at SAPO-Symposium, 1213th September, Stellenbosch. The Deciduous Fruit Grower, 28(11): 396-409.

VIDANO, C., 1964. (Discovery in Italy of Scaphoideus littoralis Ball, an American Cicadellid associated with the golden flavescence of vines. Studies of the C.N.R. working party of virus diseases: LXXVI.) Italia agric. 101(10): 1031-1049. (It), in RAE A (1968), 56: 1878 .

VIDANO, C., 1966. (Discovery of the ecology of the Cicadellid Scaphoideus littoralis Ball, on vines in its Neartic region of origin.) Annali Fac. Sci. Agr. Univ. Torino. 3: 297-302. (It, en), in RAE A (1968), 56: 2151 . 